\title{
Decontaminant solution on in vitro growth of Byrsonima intermedia seedlings
}

\author{
Solução desinfestante no crescimento in vitro de plântulas de Byrsonima intermedia
}

\author{
Luciano Coutinho Silva ${ }^{I}$ Renato Paiva ${ }^{I I}$ Daiane Peixoto Vargas ${ }^{\text {III }}$ Diogo Pedrosa Corrêa da Silva ${ }^{\text {II }}$ \\ Sandro Barbosa ${ }^{\mathrm{IV}}$ Raírys Cravo Herrerav
}

\section{ABSTRACT}

Byrsonima intermedia A. Juss., is a medicinal and fruit plant of the Cerrado in which the conventional propagation is difficult due to the presence of extremely lignified endocarps. Although sodium hypochlorite ( $\mathrm{NaOCl}$ ) is widely used in the surface decontamination, there are few reports of its effects on explant growth. The aim of this work was to study the effect of different $\mathrm{pH}$ and exposure periods of $\boldsymbol{B}$. intermedia seeds to a $\mathrm{NaOCl}$ solution. Seeds were subjected to different exposure periods (1, 5 and 10 minutes) to a $\mathrm{NaOCl}$ solution at different $\mathrm{pH}(5,7,10$ and 12) and after treatment with $\mathrm{NaOCl}$, embryos were inoculated in a WPM medium with $50 \%$ concentration of salts without sucrose, $0.5 \%$ agar and $\mathrm{pH} 5.8$ and after 75 days of culture the growth of seedlings was evaluated. The use of $\mathrm{NaOCl}$ is effective in the decontamination of $\boldsymbol{B}$. intermedia seeds, independent of $\mathrm{pH}$ variation and exposure periods and the parameters such as percentage of normal seedlings, shoot length, and number of leaves are positively affected by the use of $\mathrm{NaOCl}$ solution at pH 8.5-8.9 and by increasing the exposure period, however, the number of roots is affected only by increasing the exposure period in the NaOCl solution.

Key words: micropropagation, native plant, tissue culture, $p H$, $\mathrm{NaOCl}$.

\section{RESUMO}

Byrsonima intermedia A. Juss. é uma planta medicinal e frutífera do Cerrado, cuja propagação convencional é dificil, devido à presença do endocarpo extremamente lignificado. Embora o hipoclorito de sódio (NaOCl) seja amplamente utilizado para a desinfestação superficial, existem poucos relatos de seus efeitos sobre o crescimento do explante. Neste trabalho, o objetivo foi estudar o efeito de diferentes pHs e periodos de exposição de sementes de B. intermedia em uma solução de $\mathrm{NaOCl}$. As sementes foram submetidas a diferentes tempos de exposição (1, 5 e 10 minutos) numa solução de $\mathrm{NaOCl}$ com diferentes $\mathrm{pHs}$ (5, 7, 10 e 12) e, após o tratamento com hipoclorito de sódio, os embriões foram inoculados em meio WPM com a concentração de $50 \%$ de sais sem sacarose, ágar a 0,5\% e pH 5,8 e, depois de 75 dias de cultivo, o crescimento das plântulas foi avaliado. A utilização de $\mathrm{NaOCl}$ é eficaz na desinfestação de sementes de B. intermedia, independente da variação do $\mathrm{pH}$ ou dos periodos de exposição. $A$ porcentagem de plântulas normais, o comprimento da parte aérea e o número de folhas são positivamente afetados pela utilização de solução de $\mathrm{NaOCl}$ a $\mathrm{pH}$ de 8,5-8,9 ou pelo aumento do período de exposição, enquanto o número de raizes é afetado apenas pelo aumento do período de exposição na solução $\mathrm{NaOCl}$.

Palavras-chave: micropropagação, planta nativa, cultura de tecidos, $\mathrm{pH}, \mathrm{NaOCl}$.

\section{INTRODUCTION}

Byrsonima intermedia A. Juss. is a native and medicinal and fruit plant of the Cerrado (HERRERA et al., 2011) that presents difficulties for the propagation by seeds (LORENZI, 2002) due to the presence of extremely lignified endocarps (SOUTO \& OLIVEIRA, 2005). As growth rooms and culture media, in vitro culture environments present ideal conditions for the growth of fungi and bacteria, thus, the explant decontamination is a critical factor to any

'Departamento de Biologia Celular e Molecular, Centro de Biotecnologia, Universidade Federal da Paraíba (UFPB), Campus I, 58051-900, João Pessoa, PB, Brasil. E-mail: lucoutsilva@yahoo.com.br. Correspondent author.

IISetor de Fisiologia Vegetal, Departamento de Biologia, Universidade Federal de Lavras (UFLA), Lavras, MG, Brasil.

IIIEmbrapa Clima Temperado, Pelotas, RS, Brasil.

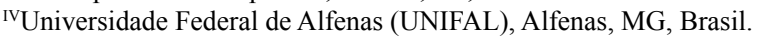

vUniversidade Federal do Pará (UFPA), Altamira, PA, Brasil. 
tissue culture assay that uses plant material from $e x$ vitro sources. When this treatment is not successful, the progress of in vitro culture studies becomes nonviable (GEORGE et al., 2008).

A decontaminant agent should eliminate microorganisms and, at the same time, not negatively affect the development of the explant and a variety of decontaminants can be used, such as ethanol, hydrogen peroxide, mercuric chloride, silver nitrate and even antibiotics (YILDIZ \& ER, 2002; RIBEIRO \& TEIXEIRA, 2008). However, sodium hypochlorite $(\mathrm{NaOCl})$ has been widely used in plant surface decontamination, showing high efficiency in combating bacteria and fungi (EMMANUEL et al., 2004), for example: node segments of Annona sp (SANTANA et al., 2011); young nodal stems segments of Maclura tinctoria L. (GOMES et al., 2010); nodule segments of Annona glabra L. (OLIVEIRA et al., 2010); Rhodiola rosea L. seeds (TASHEVA \& KOSTURKOVA, 2010); flower-stalk sections of Limonium sinuatum L. Mill. (LIU et al., 2005); and seeds of Syngonanthus elegantulus Ruhland (PÊGO et al., 2013).

The antimicrobial activity of $\mathrm{NaOCl}$ is mainly attributed to hypochlorous acid $(\mathrm{HOCl})$ which presents low molecular weight allowing penetration the cell wall of the microorganism (LEN et al., 2002) and its concentration is increased by the addition of $\mathrm{NaOCl}$ or by lowering the solution $\mathrm{pH}$. However, $\mathrm{HOCl}$ reversibly dissociates into $\mathrm{H}^{+}$ and $\mathrm{OCl}^{-}$, which presents less pronounced biocidal action, and the $\mathrm{pH}$ of the solution influences the final balance of these elements (CHUN et al., 1997; EMMANUEL et al., 2004).

Although $\mathrm{NaOCl}$ is largely used to explants surface decontamination following plant tissue culture experiments, information about the $\mathrm{pH}$ of that solution influencing the in vitro growth of explants is still scarce. In this context, the aim of this study was to evaluate the growth of $\boldsymbol{B}$. intermedia seedlings cultivated in aseptic conditions after seed decontamination at different periods of exposure to a $\mathrm{NaOCl}$ solution with different $\mathrm{pH}$.

\section{MATERIALS AND METHODS}

Mature fruits of $\boldsymbol{B}$. intermedia were collected from a natural population in the south of Minas Gerais State, Brazil, located at $918.0 \mathrm{~m}$ altitude, latitude $21^{\circ} 14^{\prime} \mathrm{S}$ and longitude $44.9^{\circ} 00^{\prime} \mathrm{W}$ GRW. After harvesting, fruits were pulped, soaked in sodium hydroxide $(\mathrm{NaOH}) 0.1 \mathrm{M}$ for 5 minutes and then washed in running water for 10 minutes.
The pyrene (endocarp) were dried in the shade and stored at $4^{\circ} \mathrm{C}$ in paper bags for a week before being manually opened with the aid of a mechanical press allowing the seeds extraction.

Variation of $\mathrm{NaOCl}$ solution $\mathrm{pH}$

In this work, commercial $\mathrm{NaOCl}$ presenting $2 \%$ active chlorine and $\mathrm{pH} 11.6$ was used to seeds surface decontamination. The solution $\mathrm{pH}$ was adjusted with $\mathrm{HCl}$ and $\mathrm{NaOH}$, both at $0.1 \mathrm{~N}$, using the Tec-3MP TECNAL $\mathrm{pH}$ meter.

\section{Decontamination and in vitro culture}

In laminar airflow, the seeds were immersed in alcohol $70 \%(\mathrm{v} / \mathrm{v})$ for 30 seconds, then in a solution of $\mathrm{NaOCl} 50 \%$ (v/v) with $1.0 \%$ active chlorine (final concentration). Four different variations of $\mathrm{pH}(5$, 7, 10 and 12) combined with three exposure times (1, 5 and 10 minutes) were tested performing an experiment of 12 treatments $(\mathrm{NaOCl} \mathrm{pH}$ x exposure times) with 15 replicates and just after the exposure to the decontaminant solution, the seeds were washed three times in sterile distilled water, and their coats were removed with forceps.

The culture medium used was WPM (LLOYD \& McCOWN, 1980), with 50\% of the salt concentration, no sucrose, $0.5 \%$ agar and $\mathrm{pH}$ ajusted to 5.8 prior to autoclaving at $121^{\circ} \mathrm{C}$ for 20 minutes according to the protocol established by NOGUEIRA et al. (2004); only one embryo was inoculated in each test tube $(25 \times 150 \mathrm{~mm})$ containing $10 \mathrm{~mL}$ of WPM culture medium and each tube represented one replicate.

After inoculation, the embryos were maintained in a growth chamber under irradiance of $63 \mu \mathrm{mol} \mathrm{m} \mathrm{m}^{-2} \mathrm{~s}^{-1}, 16$-hour photoperiod and temperature of $25 \pm 2{ }^{\circ} \mathrm{C}$. At 75 days of cultivation the following parameters were evaluated: (i) percentage of normal seedlings; and for each explant, (ii) shoot length, (iii) longest root length, (iv) number of leaves and (v) number of roots.

The measurement of shoot length and longest root was performed using a calliper and for the number of leaves, all those below the first apical pair, were counted. For number of roots, the total number was recorded and regarding the development of normal seedlings, it was expected that they should present normal growth of roots and shoots.

Statistical analyses

Prior ANOVA, performed using SISVAR ${ }^{\circledR}$ statistical software (FERREIRA, 2011), the data were transformed through the square root of $\mathrm{Y}+0.5$ and the 
averages analyzed by linear regression $(\mathrm{P} \leq 0.05)$ in a completely randomized factorial design: four $(\mathrm{pHs}) \mathrm{x}$ three (exposure time).

\section{RESULTS AND DISCUTION}

According to ANOVA, significant differences were observed for variation of the $\mathrm{pH}$ of $\mathrm{NaOCl}$ solution to the parameters: shoot length $(p=0.0232)$; number of leaves $(p=0.0183)$ and number of roots $(\mathrm{p}=0.0436)$ per explant; and percentage of normal plants $(\mathrm{p}=0.0142)$. For the variable period of exposure to $\mathrm{NaOCl}$ solution, the parameters: shoot length $(\mathrm{p}=0.0148)$, longest root length $(\mathrm{p}=0.0007)$; number of leaves $(\mathrm{p}=0.0063)$ and number of roots $(p=0.0027)$ per explant; and percentage of normal plants $(p=0.0002)$ were also significant. The longest root length was not affected by the $\mathrm{pH}$ of the $\mathrm{NaOCl}$ and the interaction: ( $\mathrm{pH}$ of $\mathrm{NaOCl}$ solution $\mathrm{x}$ period of exposure) showed no significance for any parameter assessed. The highest percentage of normal plants $(26 \%)$ was achieved at $\mathrm{pH} 8.9$, according to derivation of regression equation, or when the seeds were exposed to a $\mathrm{NaOCl}$ solution for 10 minute (29.9\%) (Figure 1).

According to LORENZI (2002) the Byrsonima genus usually presents a low germination rate and slow seedling emergence. In addition, the embryo extraction process is very harmful and could cause mechanical damage in the embryonic axis, thus reducing the percentage of normal seedlings. Moreover, in the cotyledons, numerous droplets of phenolic compounds are found and the embryonic axis is very short (SOUTO \& OLIVEIRA, 2005). Phenolic compounds may prevent germination occurring, and its effects are already well known, for instance, papaya seed germination is affected by the presence of phenols in the sarcotesta (TOKUHISA et al., 2007) and, according to TESIO et al. (2011), shoot extracts from Helianthus tuberosus L. contain bioactive phenolic compounds, able to cause inhibitory effects on lettuce seed germination and seedling growth. Thus, physical and/or chemical factors related to $\boldsymbol{B}$. intermedia seeds may have affected the germination leading to this low percentage of normal seedlings.

The best performance for shoot length $(2.7 \mathrm{~mm})$, number of leaves (1.8) and number of roots (0.7) was achieved with $\mathrm{NaOCl}$ solution at $\mathrm{pH} 8.5$, 8.7 and 8.7 , respectively, according to the equations for these three parameters (Figure 2a). Regarding the duration of exposure to this solution, we observed an increasing linear effect for shoot length $(2.6 \mathrm{~mm})$, longest root length $(9.9 \mathrm{~mm})$, number of roots $(0.7)$ and number of leaves (1.8) when the equation was

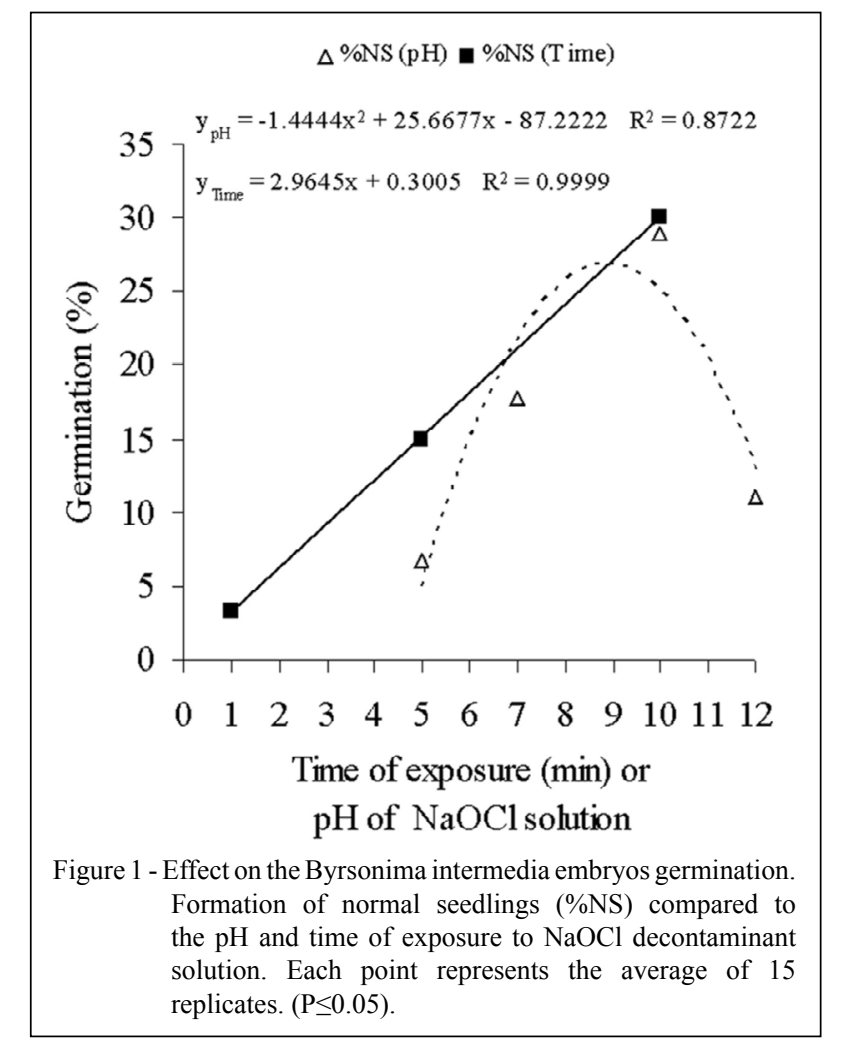

Ciência Rural, v.45, n.4, abr, 2015. 
applied for 10 minutes of exposure, respectively (Figure 2b).

Regardless of the variation of the $\mathrm{pH}$ of $\mathrm{NaOCl}$ or the period of exposure to this solution, decontamination was $100 \%$ efficient. We conducted an additional treatment (control), which presented $100 \%$ contamination, where seeds were only immersed in $70 \%$ alcohol (v/v) for 30 seconds and then rinsed in sterile distilled water three times before removing the integuments.

In this work, decontamination was efficient at all $\mathrm{pHs}$ tested, which differs from results reported by CHUN et al. (1997) where these authors showed that lowering the $\mathrm{pH}$ of $\mathrm{NaOCl}$ increased the efficiency of decontamination of rice seeds where, bacterial and fungal contaminations were effectively removed at $\mathrm{pH} 2-7$ and 2-5, respectively, however, the highest germination rate $(100 \%)$ was achieved when rice seeds were treated with $\mathrm{NaOCl}$ at $\mathrm{pH}$ 11.6.

Apparently the triple-rinse routinely applied to explants undergoing decontamination does not remove all the components of the $\mathrm{NaOCl}$ solution, maintaining a residual effect on the explant.
A reduction of in vitro contamination due to residual effects from the chlorinated water used for rinsing of glassware was showed by TEIXEIRA et al. (2008) when these authors inoculated explants of Eucalyptus pellita $\mathrm{F}$. Muell in the culture medium without autoclaving, contamination was $100 \%$.

When the tubes were soaked in a $\mathrm{NaOCl}$ solution with $0.001 \%$ of total active chlorine, with subsequent distribution of non-sterile culture medium in laminar airflow, the contamination was reduced by $60 \%$, thus confirming the effect of residual components in $\mathrm{NaOCl}$. A positive effect on the growth of in vitro Sequoia sempervirens L. seedlings was reported by (RIBEIRO, et al., 2011) when $\mathrm{NaOCl}$ was used as a sterilizing chemical medium.

This residual effect was also observed even in control of endogenous contaminants (TEIXEIRA et al., 2008) and these authors observed that culture media treated with concentrations of less than $0.005 \%$ of total active chlorine, showed contamination at the base of the explant, featuring endogenous contamination. When these authors used culture media treated with concentrations greater than

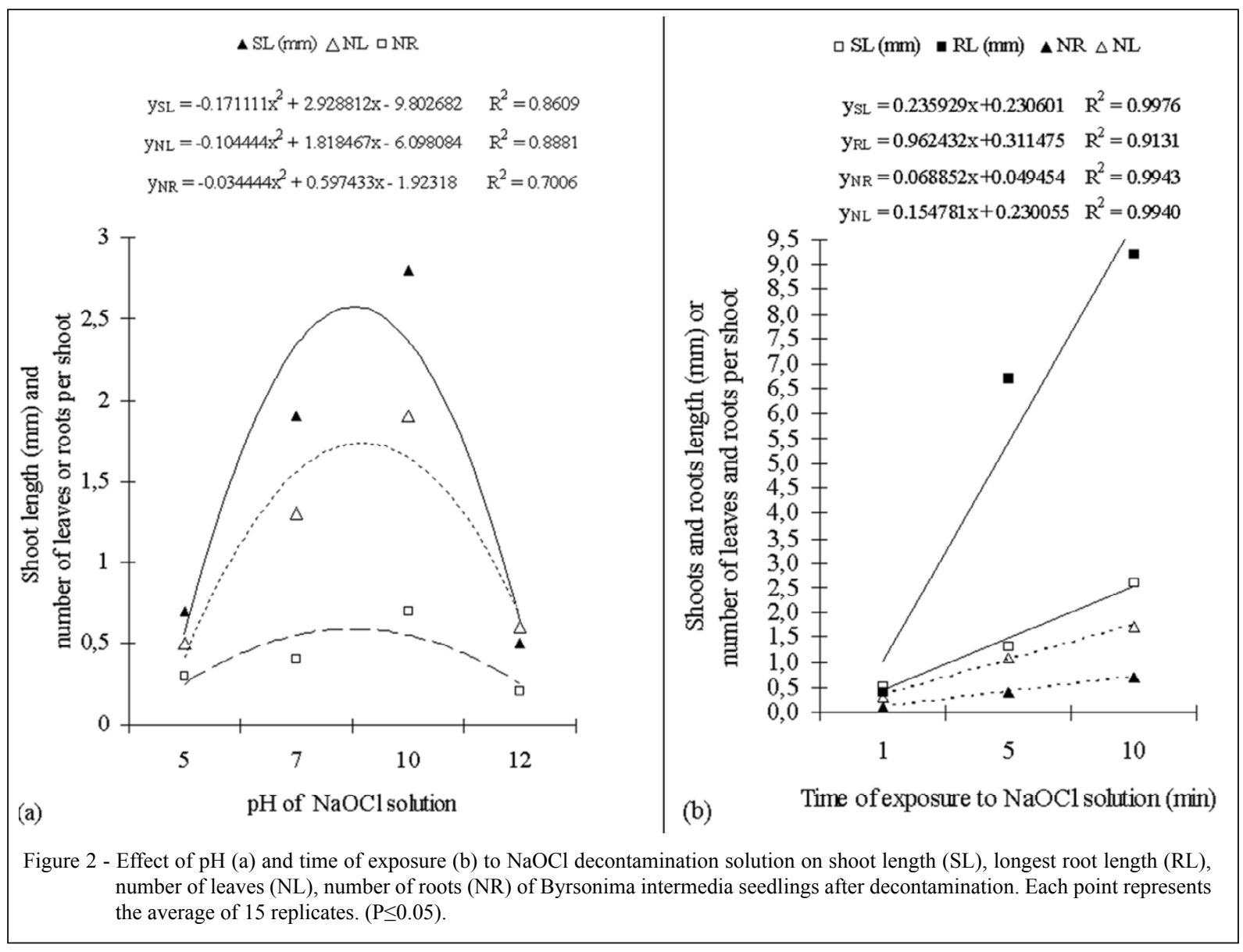

Ciência Rural, v.45, n.4, abr, 2015. 
$0.005 \%$ of total active chlorine, no contamination was found, reaffirming the residual effect of the agent, in this case, acting as a culture medium sterilizer.

Although all decontamination treatments have been effective, seedling growth was positively affected using $\mathrm{NaOCl}$ at pHs ranging 8.5-8.9, providing pronounced seedling growth when the seeds were exposed for 10 minutes at that solution. At these $\mathrm{pHs}$, both components $\mathrm{HOCl}$ and $\mathrm{OCl}^{-}$are present in the solution in equivalent amounts (EMMANUEL et al., 2004). Thus, triple-rising may not completely remove these components of the $\mathrm{NaOCl}$ solution and the residual effect could continue to positively influence the growth of explants. However, the use of $\mathrm{NaOCl}$ solution in highly alkaline $\mathrm{pH}$ positively affected rice seedling development. But, when the seeds were treated with $\mathrm{NaOCl}$ at $\mathrm{pH} 11.6$ was observed $100 \%$ germination, compared to $42 \%$ when treated at pH 3 (CHUN et al., 1997).

The use of $\mathrm{NaOCl}$ in the culture medium as a chemical sterilizer, not only was effective in sterilizing the medium, but also favoured the elongation of shoots of $\boldsymbol{E}$. pellita (TEIXEIRA et al., 2008). The increase in the number and fresh weight of shoots of pineapple was confirmed when $\mathrm{NaOCl}$ was added in the culture medium (TEIXEIRA et al., 2006), and this increase could be linked to photosynthesis as chlorine presents a catalytic role in the photosynthetic process, in addition, chlorine is a micro nutrient (EMMANUEL et al., 2004).

In this experiments, was proved that the $\mathrm{pH}$ of $\mathrm{NaOCl}$ influences seedling development once the largest growth of Byrsonima intermedia seedlings can be directly related to the residual effect of $\mathrm{NaOCl}$ solution used at different $\mathrm{pHs}$ to seeds decontamination which allowed a greater interaction with the explant.

\section{CONCLUSIONS}

The use of $\mathrm{NaOCl}$ was effective for Byrsonima intermedia seeds decontamination independently of the $\mathrm{pH}$ variation or period of exposure to that solution; for a better seedling growth an intermediate range of $\mathrm{pH} 8.7$ and 10 minutes of exposure to $\mathrm{NaOCl}$ decontamination solution is recommended.

\section{ACKNOWLEDGEMENTS}

The authors would like to thank Fundação de Amparo à Pesquisa do estado de Minas Gerais (FAPEMIG), Conselho Nacional de Desenvolvimento Científico e Tecnológico (CNPq) and Coordenação de Aperfeiçoamento de Pessoal de Nível Superior (CAPES)

\section{REFERENCES}

CHUN, S.-C. et al. Sodium hypochlorite: effect of solution $\mathrm{pH}$ on rice seed disinfestation and its direct effect on seedling growth. Plant Diseases, v.81, n.8, p.821-824, 1997. Avaliable from: $<$ http://dx.doi.org/10.1094/PDIS.1997.81.7.821>. Accessed: Mar. $19,2012$.

EMMANUEL, E. et al. Toxicological effects of disinfections using sodium hypochlorite on aquatic organisms and its contribution to AOX formation in hospital wastewater. Environment International, v.30, n.7, p.891-900, 2004.

FERREIRA, D.F. SISVAR: a computer statistical analysis system. Ciência e Agrotecnologia, v.35, n.6, p.1039-1042, 2011. Avaliable from: <http://dx.doi.org/10.1590/S1413-70542011000600001>. Accessed: Mar. 19, 2012.

GEORGE, E.F. et al. Plant propagation by tissue culture. The background. 3.ed. London: Springer, 2008. V.1, 709p.

GOMES, G.A.C. et al. Micropropagation of Maclura tinctoria L.: an endangered woody species. Revista Árvore, v.34, n.1, p.25-30, 2010. Avaliable from: $<$ http://dx.doi.org/10.1590/S010067622010000100003>. Accessed: Mar. 19, 2012.

HERRERA, R.C. et al. Índice mitótico e viabilidade celular de calos embriogênicos de murici-pequeno. Revista Ciências Agrárias, v.54, n.1, p.28-32, 2011. Avaliable from: $<$ http://doi. editoracubo.com.br/10.4322/rca.2011.035>. Accessed: Mar. 19, 2012.

LEN, S.-V. et al. Effects of storage conditions and $\mathrm{pH}$ on chlorine loss in electrolyzed oxidizing (EO) water. Journal of Agricultural and Food Chemistry, v.50, n.1, p.209-212, 2002. Avaliable from: $<$ http://dx.doi.org/10.1021/jf010822v>. Accessed: Mar. 19, 2012.

LIU, T.-H.A. et al. Control of leaf-tip necrosis of micropropagated ornamental statice by elimination of endophytic bacteria. In Vitro Cellular \& Developmental Biology - Plant, v.41, n.4, p.546-549, 2005. Avaliable from: <http://dx.doi.org/10.1079/IVP2005673>. Accessed: Mar. 19, 2012.

LLOYD, G.; MCCOWN, B. Use of microculture for production and improvement of Rhododendron spp. HortScience, v.15, n.3, p.416-417, 1980.

LORENZI, H. Árvores brasileiras: manual de identificação e cultivo de plantas arbóreas nativas do Brasil. São Paulo: Nova Odessa, 2002. V.1, 386p.

NOGUEIRA, R.C. et al. In vitro germination of (Byrsonima intermedia A. Juss.). Ciência e Agrotecnologia, v.28, n.5, p.10531059, 2004. Avaliable from: <http://dx.doi.org/10.1590/S141370542004000500012>. Accessed: Mar. 19, 2012.

OLIVEIRA, L.M. et al. Effects of cytokinins on in vitro mineral accumulation and bud development in Annona glabra L. Ciência e Agrotecnologia, v.34, n.6, p.1439-1445, 2010. Avaliable from: <http://dx.doi.org/10.1590/S1413-70542010000600012>. Accessed: Mar. 19, 2012.

PÊGO, R.G. et al. Micropropagation of Syngonanthus elegantulus. Ciência e Agrotecnologia, v.37, n.1, p.32-39, 2013. Avaliable from: $<\mathrm{http} / / / \mathrm{dx}$.doi.org/10.1590/S1413-70542013000100004>. Accessed: Jan. 10, 2014. 
RIBEIRO, J.M. et al. In vitro culture of Sequoia sempervirens L. on nutritive media sterilized with sodium hypochlorite. Ciência Florestal, v.21, n.1, p.77-82, 2011.

RIBEIRO, J.M.; TEIXEIRA, S.L. Potassium nitrate substitution for potassic saltpetre on preparation of plant tissue culture nutritive media esterilized with sodium hypochlorite. Ciência e Agrotecnologia, v.32, n.4, p.1209-1213, 2008. Avaliable from: <http://dx.doi.org/10.1590/ S1413-70542008000400026>. Accessed: Mar. 19, 2012.

SANTANA, J.R.F. et al. Effect of different carbon sources on the in vitro multiplication of Annona sp. Ciência e Agrotecnologia, v.35, n.3, p.1413-7054, 2011. Avaliable from: <http://dx.doi.org/10.1590/ S1413-70542011005000002>. Accessed: Mar. 19, 2012.

SOUTO, L.S.; OLIVEIRA, D.T. Morphology, anatomy, and development of Byrsonima intermedia A. Juss. (Malpighiaceae) fruit and seed. Revista Brasileira de Botânica, v.28, n.4, p.697712, 2005. Avaliable from: <http://dx.doi.org/10.1590/S010084042005000400005>. Accessed: Mar. 19, 2012.

TASHEVA, K.; KOSTURKOVA, G. Bulgarian golden root in vitro cultures for micropropagation and reintroduction. Central European Journal of Biology, v.5, n.6, p.853-863, 2010 Avaliable from: <http://dx.doi.org/10.2478/s11535-010-0092-3>. Accessed: Mar. 19, 2012.
TEIXEIRA, S.L. et al. Use of sodium hypochlorite in sterilization of culture medium for multiplication of Eucalyptus pellita L. Ciência Florestal, v.18, n.2, p.185-191, 2008.

TEIXEIRA, S.L. et al. Influence of $\mathrm{NaClO}$ on nutrient medium sterilization and on pineapple (Ananas comosus cv 'Smooth cayenne') behavior. Plant Cell Tissue and Organ Culture, v.86, n.3, p.375-378, 2006. Avaliable from: < http://dx.doi.org/10.1007/ s11240-006-9121-3>. Accessed: Mar. 19, 2012.

TESIO, F. et al. Allelochemicals identified from Jerusalem artichoke (Helianthus tuberosus L.) residues and their potential inhibitory activity in the field and laboratory. Scientia Horticulturae, v.129, n.3, p.361-368, 2011. Avaliable from: $<$ http://dx.doi.org/10.1016/j. scienta.2011.04.003>. Accessed: Mar. 19, 2012.

TOKUHISA, D. et al. Phenolic compound inhibitors in papaya seeds (Carica papaya L.). Revista Brasileira de Sementes, v.29, n.3, p.180-188, 2007. Avaliable from: < http://dx.doi.org/10.1590/ S0101-31222007000300022>. Accessed: Mar. 19, 2012.

YILDIZ, M.; ER, C. The effect of sodium hypochlorite solutions on in vitro seedling growth and shoot regeneration of flax (Linum usitatissimum). Naturwissenschaften, v.89, n.6, p.259-261, 2002. Avaliable from: <http://dx.doi.org/ 10.1007/s00114-0020310-6>. Accessed: Mar. 19, 2012. 